
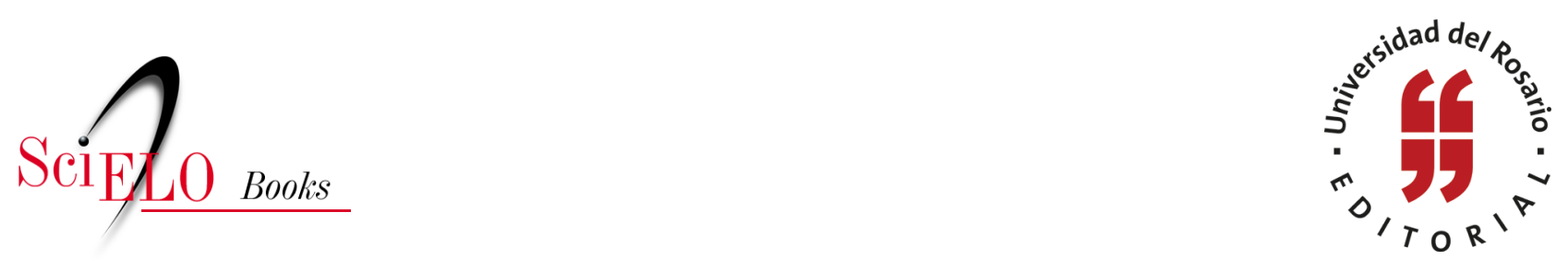

\title{
8. La mamita Gélica
}

César Augusto Tapias Hernández

TAPIAS HERNÁNDEZ, C.A. La mamita Gélica. In: Historias de familia: Etnografía delirante sobre el amor, la violencia y las drogas [online]. Bogotá: Editorial Universidad del Rosario, 2014, pp. 33-35. Textos de ciencias humanas collection. ISBN: 978-958-738-543-4. https://doi.org/10.7476/9789587385434.0009.

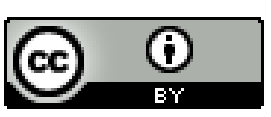

All the contents of this work, except where otherwise noted, is licensed under a Creative Commons Attribution 4.0 International license.

Todo o conteúdo deste trabalho, exceto quando houver ressalva, é publicado sob a licença Creative Commons Atribição 4.0.

Todo el contenido de esta obra, excepto donde se indique lo contrario, está bajo licencia de la licencia $\underline{\text { Creative }}$ Commons Reconocimento 4.0 . 


\title{
8. La mamita Gélica
}

\author{
La muchach a que habia franqueado la montaña porque se \\ habia sentido impelida por una esencia interior nueva, formaba \\ parte de las cuidadoras del agua. \\ Doris Lessing, La grieta
}

Fue por una mojada muy tremenda que se metió estando acalorada. En esa época, dice ella, andaban muy mal. "En esos días se me murieron las chiquitas: Aura Rosa, Luz María y Martha Elena y un varoncito llamado H. ¡El primer H!”.

Una de ellas había estado muy enferma y la abuela toda decidida y sin importarle nada distinto a sus hijos fue a llevarla al hospital. Un carro las llevó en la parte de atrás hasta San Cristóbal. Ahí fue donde se mojó... Las cogió un aguacero en el camino.

- Fonso nos había dejado por irse con otra vieja por allá donde trabajaba. Francisco, un hermano de él y yo, lo vimos. Era una que había sido dizque muy amiga mía... Desde eso no dejé entrar más mujeres a esta casa.

Mi abuela y sus hijos vivían en Bello, por los tejares, al lado de los papás de Fonso. Por aquellos días en que el amor iba dejando de ser, o se iba haciendo otra cosa... don Guillermo, el suegro de mamita, les pagaba el rancho. El viejo Guille como que era muy buena gente. Sin embargo, fue doña Abigaíl, su mujer, quien muy solidaria corrió a darle a mamita Gélica una bebida de sauco, cebada, caracucho blanco y malva cuando lo de la mojada esa, pero se la dio fría, cuando tenía que ser caliente. Y la abuela es reiterativa con esa sentencia: "Me la tenía que tomar era caliente, no fría, como ella me la dio...”.

Esa, según dice la mamita, fue la razón que le dio el doctor sobre su eterna enfermedad: "pa'l pecho cualquier cosa tenía que haber sido caliente". 
—Desde ahí, fue que empecé con esta asfixia, porque antes nunca la tuve. Yo no nací con eso.

— ¿Gélica, vos pensás que tu suegra te quiso hacer mal?

-Yo no sé. Pero tan raro que ellos siempre que venían me dejaban enferma... Toda la semana siguiente quedaba mal y hasta me tenían que hospitalizar.

A la mamita entonces se le volvió costumbre con los años ir al Seguro Social por lo del asma, y aunque varias veces realmente estuvo muy mal y la hospitalizaron, ella prefería no dejarse coger ventaja y, así fuera sola, cogía un taxi y se iba en el momento menos pensado si es que se sentía más mal de lo normal... Es que normalmente el baño de la mañana la molestaba un poco, pero ella sola se componía a veces, sentándose en la mesa de la cocina, en su puesto junto al fogón, dándole la espalda a la ventana que da al patio de la casa de abajo... Pero otras veces tenía que irse rápido adonde el médico. Y si de pronto llegaba y había mucha gente esperando turno en urgencias, para no esperar mucho, mi abuela tosía y tosía, fingiendo un poco la voz y la ausencia de aire y se lograba entrar a la sección de nebulización. Allí la sentaban y la ponían a inhalar droga; digo, medicamentos. Al ratico salía riendo y me mandaba hacer la fila para reclamarle los remedios... Ya dizque la había visto el doctor y listo. Muchas veces podía regresar a la casa de inmediato. Otras, se quedaba hospitalizada, preocupada por los quehaceres de su casa.

En aquellos malos días cuando murieron algunos hijos, hasta el tío Miro llegó a estar muy mal, lo único que podían comer era "Agua sal”. Las cosas mejoraron un poco solo cuando Fonso se colocó en las Empresas Públicas. Al papito yo siempre lo vi muy responsable, sobre todo cuando mis primos y yo éramos niños. No había diciembre que no nos diera carritos de aguinaldo, pero mamita dice que fue que doña Abigaíl quien lo corrigió, y eso porque hasta ella tuvo que demandarlo. Le embargó el sueldo. Solo así empezaron a superar tan mala racha. Ya en la casa de El Pedregal, el acomodo de tanta gente fue aparentemente sencillo. Instalados en casa propia, Melia, Hael, Rubiela e Ilsa dormían en una habitación, de a dos en cada cama. Alberto y Miro, H y Raúl en otra, igual, compartiendo camas, Will y Hétor en la piecita de adelante y el niño con los cuchos en la habitación. El niño era Ed... el niño, siempre al lado de mi tío $\mathrm{H}$, el diablo. De $\mathrm{H}$ dice la mamita que cuando lo bañaba, lo sacaba afuera a asolearse y se le volaba, y se le paraba encima a gallina, un vecinito hijo de doña Filomena y se le orinaba encima... "H era malo-malo desde pequeño y enfermo por conseguir plata”.

Tanto que sacaba cualquier cosa y la cambiaba o buscaba la forma de venderla... de hacerla plata, y de la escuela mandaban a cada rato notas porque les robaba 
plata hasta a las maestras... y que a los ocho años se metió donde un vecino y se sacó un reloj...

Quizás sea difícil de imaginar una casa con tanta gente y con ciertas “joyas" entre los propios hermanos... Y los tropeles, la cantidad de tropeles que debieron de haber tenido. Cuenta Gélica que fulano no le daba plata a mengano y por eso este lloraba, o que a zutano no le gustaba que perano se le pusiera su ropa. Sin embargo, el bullicio de aquella época lastima a la abuela, aun cuando es solo un recuerdo ya. Hoy después de tanta gente... de tanto tiempo, se ha quedado sola. Hasta el papito Fonso con los días se desvaneció, dejó de existir...

Su esperanza siempre fue Ed. Mi abuela, igual como esperan los claveles el rocío, siempre esperaba que estuviera ahí con ella; pero Ed también se esfumó...

-Ed debe de estar flotando por ahí. El haber sido tan malo no debe permitirle aún entrar al cielo, entonces está como esperando...

Hoy la casa está vacía. No la habita ni el ruido de la tele fantasmal encendida... Recuerdo cómo la noche la sorprendían ya dormida: la tele encendida y mamita dormida esperando-descansado... Mamita sonríe con los ojos llorosos sopesando las imágenes de ayer y de hoy contrastadas, atosigándose en la memoria de los años. Y así en el transcurso de una tarde, Gélica recuerda a cada uno de sus hijos con sus verdades...

—¿En quélugar estará $H$ ?... ¿Tendrá frío?

Una madre no deja de pensar ni en el hijo más calavera... como recuerda al más diablo de la casa; tampoco olvida al que bien podría haber sido el más juicioso de sus hijos: Hétor Mario.

-Qué pesar. Él no tuvo más que remedio que casarse.

La abuela no hizo sino criar hijos, y nietos... dice, y recuerda que en pago, papito ni ropa le volvió a dar... La veo sentada ahí, junto al fogón, hablando de sus días, de sus años... Años hace que es mi mamita y, sin embargo, siempre parecía estar estrenando nietos de tantos hijos que tuvo. Tantos que cuando trata de llamarlos, a hijos y nietos, los confunde llamándolos por mil nombres, nombres diferentes en vez del correcto, adivinando, retando a la memoria, a los años. 